(Филозофски факултет - докторске студије Језик и књижевност, Нови Сад)

\title{
ИМАНЕНТНА ПОЕТИКА ХАЗАРСКОГ РЕЧНИКА
}

\section{САЖЕТАК}

У раду се указује на образовне, васпитне и функционалне циљеве изучавања романа Хазарски речник Милорада Павића. Истовремено, испитује се проблем рецепције дела и како је оно утицало на хоризонт очекивања читалачке публлике.

Да би се проникло у пишчеву поетику, неопходно је образложити њене основне поставке, чија се упоришта налазе у самом делу. Анализом кључних сегмената романа компаративним, структуралистичким, филолошким и текст-методом, долази се до његове иманентне поетике.

КЉУЧНЕ РЕЧИ: Хазарски речник, иманентна поетика, хоризонт очекивања, интертекстуалност. 
$M$ илорад Павић је до 1984. године био, како је сам написао у Аутобиографији, најнечитанији писац у својој земљи, а од те године надаље најчитанији. ${ }^{1)}$ Том преокрету допринео је његов први роман Хазарски речник, који га је сврстао и у ред најчитанијих светских писаца. На тај начин Павић је актуелизовао проблем рецепције дела, у вези с којим је немачки филолог Ханс Роберт Јаус констатовао да је историјски живот књижевног дела незамислив без активног учешћа његовог адресата (Jaus 1991: 574). После несвакидашњег романа-речника повећао се хоризонт очекивања Павићевих читалаца који су потом добили прилику да се сретну са романом у облику укрштених речи (Преgео сликан чајем), затим је уследио роман у виду клепсидре

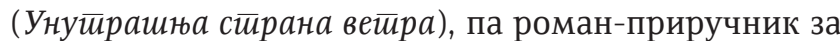
гатање тарот картама (Последња љубав у Царuі̄pagy),

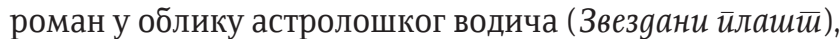

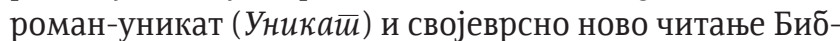
лије, роман Друі̄o йело. Критичарима је, чини се, најтеже било да прескоче „препреку” звану Хазарски речник. Познато је Павићево мишљење о критичарима, да су као преварени мужеви који увек последњи сазнају новост. Новине које је Павић Хазарским речником понудио читаоцима и смисао тих иновација расути су на страницама ове књиге и неопходно их је прикупити, да би се проникло у пишчеву поетику.

Павић сматра да је садржина романа, као на Прокрустовој постељи, била подвргавана увек истом моделу форме, истичући да сваки роман йреба gа нађе свој облик, своју а gеквайну форму. ${ }^{2)}$ Тако је, на пример, идеал Данила Киша била књига која ће моћи да се чита и као енциклопедија, а реализација те идеје назире се у Башйu, иеиеелу, односно у Реgу вожне Едуарда Сама, као и у гомилању података и докумената у Пешианику, а највише је присутан у Енциклойеguјu мрйвих. Киш је својим идеалом на неки начин потврдио Бахтинову тезу о роману који се тежњом за опширношћу и свеобухватношћ приближава енциклопедијској форми. Данило Киш и Милорад Павић, иако по много чему разнород-

1) Ауйобиоі̄pафија Милорада Павића може се наћи на пишчевој званичној интернет презентацији на адреси www.khazars.com

2) Текст Почейак и крај романа налази се на интернет адреси www.khazars.com ни писци, управо су се у овој тачки приближили један другом, услед неких општих тежњи савремене књижевности. Са друге стране, бирајући лексикографски поступак за свој роман, Павић се приближио моделу Вуковог Рјечника, у коме је сувопарна лексикографска грађа оживљена низом народних умотворина. У истом контексту, Павић у Хазарском речнику текстуалну грађу огрће формама предања, легенде и мита. Тако се, примера ради, у одредници Сйолйник (Бранковић Грі̄ур), у Црвеној књизи, кроз форму предања наводи да је Бранковић носио скуйоиену сабљу о сеgамgесей листиова која је кована све gок ковач није очитиао gевей Оченаша за реgом (Рavić 1988: 95). Самом својом тематиком - трагањем за истином о једном народу, Хазарски речник се уз извесна ограничења може посматрати и као историјски роман. На тај начин он балансира на границама жанра и представља жанровски фанйом (Delić 1991: 93). Иронију према строгом одређивању књижевних жанрова илуструје и поднаслов књиге, где стоји да је реч о роману-лексикону у 100000 речи, а који сугерише да се ради о пародији на дефиниције жанра романа на основу броја лексема - према Форстеру, роман је прича која садржи више од 50000 речи (Форстер 2002: 32).

Идеја о роману-речнику приписује се једном од демонских јунака, а уједно и носиоцу највећег броја фрагмената Павићеве поетике расутих у лексикону, протокалиграфу и надалеко чувеном фрескосликару Никону Севасту, који говори о речнику боја. Он напо-

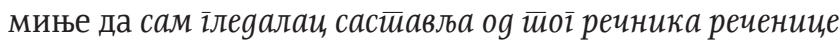

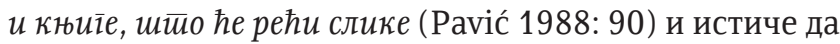
је ваннија вера ілеgања, слушања и иитиаюа о вере сликања, йојања или иичсања (Раvić 1986: 2). Овом идејом, Никон Севаст читаоце Хазарскої речника уводи на терен поетике новог писања, али и читања књижевног дела. Он и његов помоћник, Теоктист Никољски, налазе се и у средишту проблема ауторства речника о Хазарима, али и проблема ауторства уопште.

С правом се може поставити питање ко је аутор Хазарскої речника. Милорад Павић себе назива саgашњим йисием књиіе, сугеришући да она има још писаца. Одредница Мокаgаса ал Сафер из Жуйе књиіе открива да је хазарска принцеза Атех аутор првог женског при- 
мерка речника, а да је аутор мушког примерка хазарски свештеник у једном женском манастиру и један од најбољих ловаца на снове, Мокадаса ал Сафер. Своју верзију књиге он није писао за савременике и потомке, него за претке и то на древном хазарском језику из петог века. Тај чин аналоган је Павићевом замишљању читалаца-предака за које је писао свој роман-лексикон - гроф Ђорђе Бранковић, Гаврил Стефановић Венцловић, Арсеније III Чарнојевић, Захарија Орфелин (Рavić 1986: 2). Поред најстаријег, средњовековног слоја књиге, аутори Хазарскоі̄ речника могу се тражити и на преостала два - седамнаестовековном, односно барокном и двадесетовековном. Аврам Бранковић, Јусуф Масуди и Самуел Коен припадају средњем слоју речника, а заједничко им је да су сва тројица писци књиге о Хазарима (сваки своје - Црвене, Зелене и Жуиее). На овом временском нивоу значајно место у погледу ауторства имају још и Теоктист Никољски, као приређивач и Јоанес Даубманус, као штампар и издавач. Савремени, двадесетовековни писац књиге је Милорад Павић и тако постаје јасно због чега он себе назива саgашњим йuсием кюиіе . У тој игри, књижевни јунаци претворени су у писце, а сам писац постао је потенцијални књижевни јунак неког новог издања књиге о Хазарима. Сегмент исповести Теоктиста Никољског у Appendix-y I, у коме овај јунак прича како је, преписујући Жийије Св. Пейра Коришко̄, смишљено преправио текст, па је по његовом препису светац постио строгим постом пуних педесет, уместо пет дана и тако умро, Јован Делић каже да мо-

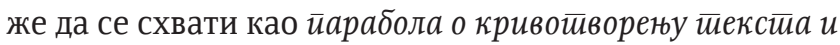

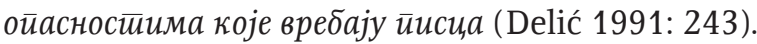

Истичући у поднаслову да његов речник представља реконструкцију првобитног (уништеног) Даубманусовог издања Хазарской речника (штампаног 1691. године на латинском језику), тј. да је реч о речнику речника, Павић ради слично што и Теоктист Никољски дописује йуђу књигу. Умберто Еко је приметио да књи-

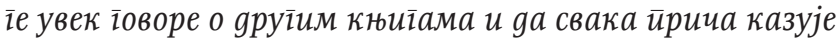
йричу која је већ казивана (према Нас̌ion 1996: 214). У том смислу, основна концепција Павићевог романалексикона ослања се на појам палимпсеста, којим он брише претходни текст (Lexicon cosri) и у новом контексту даје му ново значење. Павић налази начин да се поигра бројевима и поводом објављивања своје реконструкције Даубманусовог издања речника после 293 године, колико је требало Авраму Бранковићу, Јусуфу Масудију и Самуелу Коену, који су погинули 1689. на Дунаву, да се 1982. поново окупе у хотелу Кині̄стион у Цариграду. И сами Хазари су палимпсест, како је то приметио Марко Недић (Nedić 1986: 67). Они су изгубљени или избрисани текст историјских догађања која треба поново написати. Поступак палимпсеста Павић употребљава и у односу на сопствено књижевно дело. У Хазарском речнику налазе се мотиви већ познати из његових прича Цвейна іррознии, Вечера у Дубровнику, Парйија шаха са живим фиіуррама и других, што се мо-

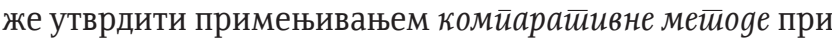
анализи тих мотива. Тај Павићев поступак заправо је илустрација тезе коју је дефинисао Мишел Фуко, рекавши да іраниие неке книіе никаgа нису јасно йовучене:

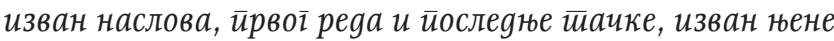
унуйрашюе конфиіураи,је и юене ауйономне форме, она

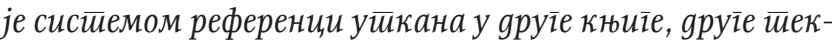
сииове, gруїе реченице: она је чвор унуйар мреже (према Нас̌ion 1996: 213-214). На тај начин, Павићево стваралаштво може да се схвати као gинамична и gифузна иелина јеgне разнолике свеукуйносиии...која йоgразуме-

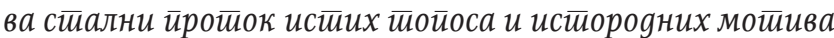
(Пијановић 1998: 51).

Дефинишући читање као сумњиву рабош̄y, Милорад Павић већ на почетку Хазарскоі речника покреће питање те демонске работе епитафом, исписаним на белини хартије: На овом месйу лежи онај иишалаи, који

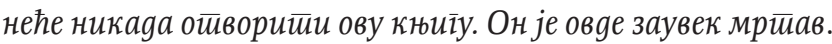
Александар Јерков ове речи тумачи као објаву смрти оних читалаца који се никада неће упустити у авантуру звану Хазарски речник, као и да сви они који отворе ову књигу (а чини се да то важи за књиге уопште) постају живи за књижевност (Јерков 1993: 22). Трагичност епитафа огледа се у чињеници да они који не читају књиге, не знају за своју gуховну смрй. Читање, тако, на неки начин, представља васкрсење. С тим у вези је и Павићево виђење књиге као куће - мало је књига у које ће се завирити, а још мање је оних у којима ће се читалац настанити на дуже време или им се враћати, тј. поново улазити у њих. Сам Павић каже да епитаф 
може да се односи и на писца који никаg не може йро-

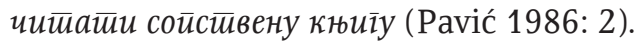

Главни носиоци Павићеве поетике новог писања и читања су Никон Севаст и његов помоћник, Теоктист Никољски. Севаст пасионирано осликава цркве све док не дозна да се појавио младић који исти посао ради подједнако добро. Тада Никон заувек остави своје четке, говорећи: Шйа ће ми gа буgем иконойисаи, као сви остиали? Саg свак може gа наслика истио шйо и ја (Рavić 1988: 91). Павић је овде сопствену мисао доделио свом јунаку, што није једини такав пример. Писац осветљава поетику новог читања кроз још једну личност - археолога и новосадског професора др Исајла Сука. Он се нада тренутку када ће човечанство устати против

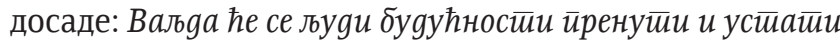

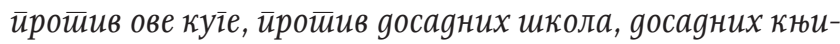
$\bar{\imath} a, \bar{u} р о \bar{u} и в$ gосаgне музике, gосаgне науке, gосаgних са-

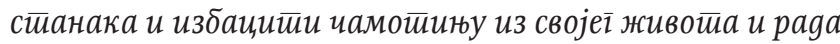
(Pavić 1988: 254). Оно што се за Хазарски речник никако не би могло рећи је да је то досадна књига, из разлога што је писац посебну приврженост и пажњу указао читаоцу, са циљем да му читање претвори у авантуру у којој би и сам активно могао да учествује. Према речима Волфганга Изера, највеће йошйоваюе које йисаи, може gа укаже читиаочевим gуховним сиоособностичма

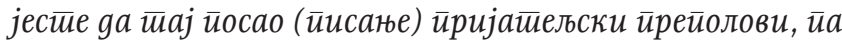
му остиави gа и он, са своје стиране, ионешйо замишља, као шйо и сам йисаи, иини (према Јерков 1990: 212). У Преиххоним найоменама, које служе да олакшају читаоцу кретање кроз текст и за које Петар Пијановић каже да се могу схватити као пародија на старе епове (Пијановић 1998: 152) (Павић уместо наклоности и савеза са музама тражи савез са читаоцем), истиче се

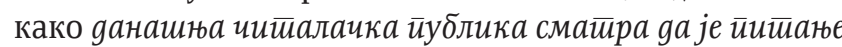

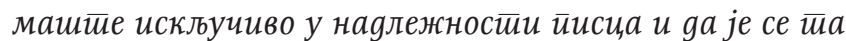

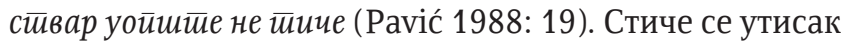
да писац апелује на читаоца да се тргне и одупре клишеима. У том контексту може се схватити и Павићева парабола о два човека која на ласима држе ухваћену пуму и који не могу да се приближе један другом, јер ће их пума напасти ако се ласа олабаве: Онај ко иийа

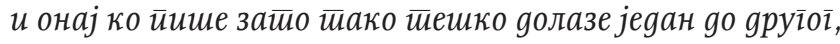
јер је између юих зајеgничка мисао ухваћена на узии,а- ма које вуку у суйройним смеровима (Раvić 1988: 19). Тумачећи сопствену књигу, Милорад Павић је рекао да је покушао да се приближи скулптури и да је у Xaзарском речнику присутан феномен гледања слике или скулптуре, где није важно од ког дела ће почети разгледање. Такав угао посматрања пружају реверзибилне уметности, какве су архитектура, сликарство и сл. Желећи да од књижевности, као нереверзибилне уметности направи реверзибилну, Павићев роман-лексикон нема класичан почетак ни завршетак, него га је допуштено читати по сопственој жељи.

У концепт поетике новог читања улази и Павићева идеја о мушком и женском примерку књиге, који се разликују у свега неколико реченица. Теоктист Никољски у Appendix-y 1 (који представља епилог барокног слоја приче, док Appendix 11 заокружује причу савременог нивоа) исказује ову идеју речима да мушке

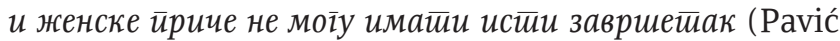
1988: 274). У одредници Црвене књиіе о Методију Солунском стоји да је за мушко читање карактеристично примање непарних, а за женско читање парних реченица неке књиге, чије се потпуно значење добија спајањем мушког и женског начина читања. Милорад Павић објашњава да разлика између два примерка његовог романа-лексикона одражава разлику мушког и женског доживљаја света - мушкарац свет доживљава изван себе, а жена свемир носи у себи (Политика 2002). Разлика у йолу књиїе делује сасвим засновано, ако се узме у обзир да је хазарска принцеза Атех израдила женски, а Мокадаса ал Сафер мушки део речника. На новој поетици читања (али и писања) заснива се и Павићев роман Уникай, који сваком читаоцу нуди јединствен и непоновљив завршетак приче.

Непрестано кретање на граници између стварног света и њему паралелних, фантастичних светова, губљење границе између уметности и живота, у Хазарском речнику има за последицу да свеши у књижевном gелу gобија свој иекксиовни лик. (Пијановић 1998: 307). Какав ће тај лик бити, зависи од ангажовања самог читаоца, јер само онај ко уме ирравим реgом gа ирочийа

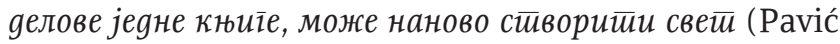
1988: 19). Ако се узме у обзир и чињеница да је приликом читања једног примерка Даубманусовог речника, који је штампан отровном бојом, читалац умирао 
на деветој страни код речи: Verbum caro factum est (реч постаде месо), сугерише се постојање йиси,а-gемијур$\bar{\imath} a$ (Пијановић 1998: 14), а такви су сви који покушавају да обједине све три верзије о хазарској полемици у једну целину и тако саставе Божанску књиіуу, која би пружила она сазнања која су људима ускраћена. Склапањем три књиге у једну, оживео би се небески Адам, човеков анђеоски предак. Аврам Бранковић се опробава као Творац, тако што од блата прави и оживљава Петкутина. Сам тај демијуршки чин је грешан, јер у себи садржи идеју којом се приближава и постаје сличан Богу. У том смислу, на временској вертикали Хазарскої речника присутни су демонски ликови који имају задатак да онемогуће склапање књиге о Хазарима у целину. На двадесетовековном нивоу књиге то је демонска породица Ван дер Спак, док је на барокном нивоу за то задужен Никон Севаст, који је спалио Бранковићев и Масудијев речник, али је Теоктист Никољски, осуђен на добро памћење, спровео у дело оно што је Севасту било стало да осујети. Као и свака друга прича у оквиру Павићевог романа-лексикона, и ова је илустрација неког сегмента пишчеве поетике. Чини се да је Павић овом двојицом јунака желео да укаже на истовремено постојање демона стваралаштва и демона разарања. Њих двојица симболиишу двојство у човеку, његову светлу и тамну страну, коју је један од Павићевих замишљених читалаца, Венцловић, метафорично назвао Црни биво у сриу. Павић је постојање те дихотомије проширио на књижевни текст.

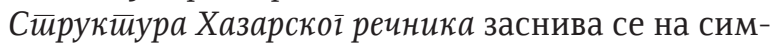
болици тројства - три су књиге, односно верзије о хазарској полемици, три су историјска времена која се везују за овај догађај, полемика је имала тројицу учесника, тројицу хроничара и три савремена истраживача. С једне стране, симболика броја три може да се схвати као Павићева тежња за превладавањем дуалистичке слике света, а с друге стране, тројство, заправо, представља јединство, потпуност једне представе, јер до истине се долази увидом у више извора.

Јован Делић је структуру Павићевог речника представио у виду призме у којој је време изражено простором, што је у складу са Бахтиновом дефиницијом времена као четврте димензије простора (Bahtin 1989: 193), али и чињеницом да Хазари буgућносй замишљају у йросииору, а никаgа у времену (Pavić 1988: 127). Јасмина Лукић Хазарски речник види као йосиимоgерну хетееройойијуㄱ) (Лукић 1993: 82), јер се у њему доводе у везу светови који егзистирају само у фиктивном, вештачки створеном простору књижевног текста и који су међусобно инкомпатибилни.

И језик Хазарскоі̄ речника има поетичку улогу. Указујући, у оквиру филолошке анализе романа, на необичне синтаксичке конструкције, метафоризацију реченица и парадокс, као једно од најприсутнијих стилских средстава, показује се да Павић тежи да се одвоји од стандардног језичког израза, стварајући тако сопствени идиом. Марко Недић је приметио да се јасно одвајају наративни делови ове књиге, у којима је смештена фабула, од лирских делова, који садрже кључ за тумачење фабулативне основе (Nedić 1986: 80).

Иако делује екуменски, Хазарски реиник указује на разлике и непомирљивост трију светова, који, сваки из свог угла, даје једину „исправну” истину. Истовремено, ова књига опомиње на трагична нестајања целих народа, њихових култура, историја и религија.

Живот је делом налик читању, па се разбијена и дестабилизована слика света неминовно одражава и на плану текста у виду распарчане, фрагментарне структуре, која само на изглед делује хаотично, а заправо је устројена по строгим правилима. Павићев роман-лексикон, како је у раду показано, крије у себи мноштво примера иманентне поетике, са функцијом да читаоцу осветле пут којим се креће кроз књижевни текст. Пажљивим праћењем успутних знакова које писац даје, може се доћи до закључка да је Хазарски реиник заснован на разбијању конвенционалне представе о роману, његовој композицији, језику итд.

Милорад Павић је овим својим делом, са књижевноисторијског аспекта, покушао да одговори на питање да ли је и колико књижевност епохе барока присутна у данашњој књижевности, а сам значај седамнаестовековног слоја речника сугерише одговор. Говорећи управо о том слоју своје књиге, Павић је констатовао да је наше gоба блине барокном неїо класичном кониеййу. То ујеgно значи gа је йреg нама ново класично gоба које ми нећемо волетии и које ће бити немилосряно ирема нама (Pavić 1986: 8).

\footnotetext{
3) Термин потиче од Мишела Фукоа.
} 
Са методичког аспекта може се закључити да је Хазарски речник дело погодно за приказивање процеса откривања и разумевања пишчеве поетике уопште. За анализу овог Павићевог романа неопходан је плурализам метода, чијом се применом спознаје тоталитет књижевноуметничког дела. Такође, на примеру Хазарскоі̄ речника показује се како једна иновативна књига најпре разара видокруг очекивања читалаца (формиран према књижевним конвенцијама), да би га, потом, проширила. Сходно томе, Павићев роман-лексикон покреће многобројна питања у синхронијској равни (у вези са референцијалним системом савремене књижевности), али и у дијахронијској равни (односећи се на повезаност рецепција књижевних дела).

\section{Svetlana S. Tornjanski Brašnjović}

\section{IMMANENT POETICS DICTIONARY OF THE KHAZARS}

\begin{abstract}
Summary
Dictionary of the Khazars balances on the borders of genre. Literary innovations that Pavic presented his first novel, increased the horizon of expectations of the readership. These innovations, the bulk of pages, it is necessary to collect in order to get familiar with the writer's poetics. The basic concept of Pavic's novel-lexicon based on the notion of palimpsest. Specifically, the Dictionary of the Khazars are already familiar motifs from a writer's story Flower fever, Dinner in Dubrovnik, The Game of Chess with living figures and others, which can be determined by applying the comparative method. In the philological analysis of the novel, the unusual syntactic structure and paradoxes, it is shown that Pavic tends to separate from the standard linguistic expression, thus creating their own idiom. Analysis of key segments of the novel using a comparative, structuralist, philological and tex method, leads to its immanent poetics.
\end{abstract}

Keywords: Dictionary of the Khazars, immanent poetics, horizon of expectations, intertextuality.

\section{Л И Т Е РА Т У РА}

- Bahtin, Mihail (1989). O romanu. Beograd: Nolit.

- Bojić, Goran (1986). Enciklopedija i leksikografija - najnovije proze Milorada Pavića i Danila Kiša. Savremenik XXXII (1-2). Beograd: Književne novine.

- Delić, Jovan (1991). Hazarska prizma. Beograd: Prosveta/ Titograd: Oktoih/ Gornji Milanovac: Dečje novine.

- Егерић, Мирослав (1997). Хазарски речник или кралевсииво светллих иуgа Милораgа Павића, Дела и gани IV. Нови Сад: Матица српска.

- Jaus, Hans Robert (1997). Horizont očekivanja publike, Teorijska misao o književnosti. Novi Sad: Svetovi.

- Јерков, Александар (1990). Нова шекстиуалносй поговор књизи Анахореш̄ у Њујорку у оквиру Сабраних gела Милорада Павића. Београд: Просвета.

- Јерков, Александар (1993). О неизїоворљивом, Савремена срйска йроза 5 (Павић и постмодерна). Трстеник.

- Kordić, Radoman (1989). Postmodernistička ukrštenica. Književna kritika XX (2). Beograd: Rad.

- Лукић, Јасмина (1993). Хазарски речник као модерна хетееройойија, Савремена срйска йроза 5 (Павић и постмодерна). Трстеник.

- Михајловић, Јасмина (1992). Прича о gуши и шелу (слојеви и значена у йрози Милораgа Павића). Београд.

- Nedić, Marko (1986). Hazarski i drugi palimpsesti Milorada Pavića, Savremenik XXXII (3): 1-2. Beograd: Književne novine.

- Pavić, Milorad (1988). Hazarski rečnik. Beograd: Prosveta: Narodna knjiga: SKZ/ Sarajevo: Svjetlost/ Priština: Jedinstvo/ Novi Sad: Matica srpska.

- Pavić, Milorad (1986). Barokni sloj u Hazarskom rečniku, Delo XXXII (32): 6. Beograd: Nolit.

- Пијановић, Петар (1998). Павић. Београд: Филип Вишњић.

- Политика 2002 - интервју са Милорадом Павићем 26. октобра 2002.

- Форстер, Едвард Морган (2002). Асйекӣи романа. Нови Сад: Orpheus.

- www.khazars.com

- Милорад Павић, Ауйобиоїрафија

- Милорад Павић, Почетак и крај романа 